Edith Cowan University

Research Online

Research outputs 2014 to 2021

2020

\title{
Energy efficiency of a flat-plate solar collector using thermally treated graphene-based nanofluids: Experimental study
}

Omer A. Alawi

Haslinda Mohamed Kamar

Hussein A. Mohammed

Edith Cowan University

A. R. Mallah

Omar A. Hussein

Follow this and additional works at: https://ro.ecu.edu.au/ecuworkspost2013

Part of the Engineering Commons, and the Physical Sciences and Mathematics Commons

10.1177/1847980420964618

Alawi, O. A., Kamar, H. M., Mohammed, H. A.Mallah, A. R., \& Hussein, O.A. (2020). Energy efficiency of a flat-plate solar collector using thermally treated graphene-based nanofluids: Experimental study. Nanomaterials and Nanotechnology, 10, 1-13. https://doi.org/10.1177/1847980420964618

This Journal Article is posted at Research Online.

https://ro.ecu.edu.au/ecuworkspost2013/9550 


\title{
Energy efficiency of a flat-plate solar collector using thermally treated graphene-based nanofluids: Experimental study
}

Nanomaterials and Nanotechnology Volume 10: $1-13$ (C) The Author(s) 2020 DOI: 10.1 I77/I8479804209646/8 journals.sagepub.com/home/nax (3)SAGE

\author{
Omer A Alawi' $\odot$, Haslinda Mohamed Kamar', \\ Hussein A Mohammed ${ }^{2}$, AR Mallah ${ }^{3}$, and Omar A Hussein ${ }^{4,5}$
}

\begin{abstract}
A covalent functionalization approach was utilized for the preparation of highly dispersed pentaethylene glycol-thermally treated graphene-water as the absorbing material inside a flat-plate solar collector. Four mass fractions of nanofluids were prepared $(0.025,0.05,0.075$, and 0.1 wt $\%$ pentaethylene glycol-thermally treated graphene-water). Graphene nanoparticles were characterized by energy dispersive X-ray analysis with a scanning electron microscope. Measurements of the thermophysical properties were subsequently carried out for the nanosuspensions. The raw investigation data were collected from an indoor flat-plate solar collector test setup. The experimental procedure included different sets of variables such as input temperatures of 303,313 , and $323 \mathrm{~K}$; fluid mass flow rate of $0.00833,0.01667$, and $0.025 \mathrm{~kg} \mathrm{~s}^{-1}$; and heat flow density of 500,750 , and $1000 \mathrm{~W} \mathrm{~m}^{-2}$. The thermophysical tests of pentaethylene glycol-thermally treated graphene-water nanofluids showed a proportional increase against weight concentrations, while the specific heat power was reduced. The tests showed an increment in energy efficiency by increasing the fluid mass flow rate and heat input. By comparison, the thermal efficiency decreased with the increasing temperature of the fluid supply. Relative to the base fluid, the energy efficiency of pentaethylene glycol-thermally treated graphene/water-based flat-plate solar collector increased to $10.6 \%, 11 \%$, and $13.1 \%$ at the three fluid mass flow rates. In conclusion, an exponential form was used to derive the thermal effectiveness of flat-plate solar collector based on the experimental data.
\end{abstract}

\section{Keywords}

Energy efficiency, flat-plate solar collector, few-layer graphene, pentaethylene glycol, thermophysical properties

Date received: 22 May 2020; accepted: 27 August 2020

Topic: Nanoparticles and Colloids

Topic Editor: Raphael Schneider

Associate Editor: Raphael Schneider

\footnotetext{
'Department of Thermofluids, School of Mechanical Engineering, Universiti Teknologi Malaysia, Skudai, Johor Bahru, Malaysia

${ }^{2}$ School of Engineering, School of Molecular and Life Sciences, Edith Cowan University, Joondalup, WA, Australia

${ }^{3}$ Department of Mechanical Engineering, University of Malaya, Kuala Lumpur, Malaysia

${ }^{4}$ Department of Mechanical Engineering, Universiti Teknologi PETRONAS, Bandar Seri Iskandar, Perak Darul Ridzuan, Malaysia

${ }^{5}$ Mechanical Engineering Department, College of Engineering, Tikrit University, Tikrit, Iraq
}

\section{Corresponding authors:}

Omer A Alawi and Haslinda Mohamed Kamar, Department of Thermofluids, School of Mechanical Engineering, Universiti Teknologi Malaysia, 8I3I0 UTM Skudai, Johor Bahru, Malaysia.

Emails: omeralawi@utm.my; haslinda@utm.my; haslinda@mail.fkm.utm.my 


\section{Nomenclature}

\begin{tabular}{|c|c|c|c|}
\hline$A_{c}$ & Collector aperture area $\left(\mathrm{m}^{2}\right)$ & K & Thermal conductivity $\left(\mathrm{W} \mathrm{m}^{-1} \dot{\mathrm{c}} \mathrm{K}^{-1}\right)$ \\
\hline $\mathrm{Ag}$ & Silver & $\dot{m}$ & Fluid mass flow rate $\left(\mathrm{kg} \mathrm{s}^{-1}\right)$ \\
\hline $\mathrm{Al}$ & Aluminum & $\mathrm{MgO}$ & Magnesium oxide \\
\hline $\mathrm{Al}_{2} \mathrm{O}_{3}$ & Aluminum oxide & MWCNT & Multi-walled carbon nanotubes \\
\hline $\mathrm{AlCl}_{3}$ & Aluminum trichloride & PEG & Pentaethylene glycol \\
\hline $\mathrm{CeO}_{2}$ & Cerium (IV) oxide & $Q_{\mathrm{u}}$ & Usable heat gain (W) \\
\hline$C_{\mathrm{p}}$ & Fluid specific heat capacity $\left(\mathrm{kJ} \mathrm{kg}^{-1} \mathrm{cK}^{-1}\right)$ & RTD & Resistance temperature detectors \\
\hline $\mathrm{Cu}$ & Copper & SEM & Scanning electron microscope \\
\hline $\mathrm{CuO}$ & Copper (II) oxide & $\mathrm{SiO}_{2}$ & Silicon dioxide \\
\hline DMF & Dimethylformamide & SWCNTs & Single-wall carbon nanotubes \\
\hline EDX & Energy-dispersive $X$-ray spectroscopy & $T_{\mathrm{a}}$ & Room temperature $(\mathrm{K})$ \\
\hline $\mathrm{Fe}_{3} \mathrm{O}_{4}$ & Iron (II, III) oxide & TGr & Thermally treated graphene \\
\hline FPSC & Flat-plate solar collector & THF & Tetrahydrofuran \\
\hline$F_{\mathrm{R}}$ & Collector heat removal factor & $T_{\mathrm{i}}$ & Input fluid temperature $(\mathrm{K})$ \\
\hline GrNPs & Graphene nanoplatelets & $\mathrm{TiO}_{2}$ & Titania \\
\hline GO & Graphene oxide & $T_{0}$ & Output fluid temperature (K) \\
\hline$G_{\mathrm{T}}$ & Heat flux intensity $\left(\mathrm{W} \mathrm{m}^{-2}\right)$ & $U_{\mathrm{L}}$ & Overall heat loss coefficient $\left(\mathrm{W} \mathrm{m}^{-2} \dot{\mathrm{c}} \mathrm{K}^{-1}\right)$ \\
\hline $\mathrm{HCl}$ & Hydrochloric acid & $\mathrm{WO}_{3}$ & Tungsten $(\mathrm{VI})$ oxide \\
\hline \multicolumn{4}{|c|}{ Greek symbols } \\
\hline$\mu$ & Viscosity (mPaćs) & $\tau \alpha$ & Transmittance-absorptance product \\
\hline$\eta_{\mathrm{c}}$ & Collector performance & $\phi$ & Mass concentration (wt\%) \\
\hline$\rho$ & The fluid density $\left(\mathrm{kg} \mathrm{m}^{-3}\right)$ & & \\
\hline
\end{tabular}

\section{Introduction}

One of the versatile solar conversion devices for residential and industrial applications is the thermal active surface (solar collector). The solar collector absorbs and converts solar energy to heat in a suitable base fluid, for example, ethylene glycol, oil, or water $\left(\mathrm{H}_{2} \mathrm{O}\right) .{ }^{1-3}$ The flat-plate solar collector (FPSC) device consists of an absorber plate that can be made of copper $(\mathrm{Cu})$ or aluminum $(\mathrm{Au})$ materials and coated with a specific surface coating to increase the absorption of radiation. The header and riser pipelines are entirely connected on the outside of the absorber sheet to ensure the heat transfer fluid is appropriately circulated. A transparent sheet of glass is often used to reduce heat loss by radiation and convection. The concern about solar collectors is not only their reduced overall energy efficiency but also the limited convective heat transfer propensity of the absorbent plate and the absorbing medium. ${ }^{4,5}$

One of the innovative ways to increase the performance of flat-plate collectors is to use nanofluids as working fluids, ${ }^{6-11}$ rather than conventional liquids. Initially, Choi and Eastman ${ }^{12}$ suggested the use of nanofluid, defined as a colloidal mixture of solid nanoparticles $(<100 \mathrm{~nm})$ suspended in classical fluids. They have excellent thermophysical properties, providing an efficient heat transfer cycle, as well as more effective heat absorption compared with conventional liquids. ${ }^{13-17}$ Several metal nanomaterials, such as $\mathrm{Cu}, \mathrm{Al}$, and silver, ${ }^{18-20}$ along with various forms of metal oxides, such as copper oxide, aluminum oxide $\left(\mathrm{Al}_{2} \mathrm{O}_{3}\right)$, iron oxide, and magnesium oxide, were used as additives for working fluids inside FPSCs. ${ }^{21}$ Due to its extreme thermal conductivity, moderate density, and low preparation cost, $\mathrm{Al}_{2} \mathrm{O}_{3}-\mathrm{H}_{2} \mathrm{O}$ nanofluid is the most commonly used medium among other metallic oxides-based nanofluids in the FPSC. Sundar et al. ${ }^{22}$ had explored the effect of using $\mathrm{Al}_{2} \mathrm{O}_{3}$ nanofluids under a turbulent flow regime in a flat-plate collector. They measured two concentrations of nanofluid in distilled water (DW): 0.1 and $0.3 \mathrm{wt} \%$ of $20 \mathrm{~nm} \mathrm{Al}_{2} \mathrm{O}_{3}$-NPs. The twisted taped FPSC was measured at three distinct pitch ratios $(H / D)$ of 5,10 , and 15. Also, the FPSC without the twisted tapes was tested. Their results showed that the efficiency of the FPSC with a twisted tape of $H / D=5$ was improved by $18 \%$ compared to the FPSC with $\mathrm{H}_{2} \mathrm{O}$ as a heat transfer fluid, for nanoparticles content of $0.3 \mathrm{wt} \%$ and a flow rate of $5 \mathrm{~kg} \mathrm{~min}^{-1}$.

Specific samples of crystallized semiconductor oxide nanomaterials have been used as heat exchange fluids in FPSCs, such as titanium dioxide, cerium dioxide, and tungsten trioxide. ${ }^{23-25}$ Despite its poor thermal conductivity, silicon dioxide $\left(\mathrm{SiO}_{2}\right)$ was also used by many researchers as a $\mathrm{H}_{2} \mathrm{O}$-dependent nanofluid in FPSCs. Noghrehabadi et al. ${ }^{26}$ used $1 \mathrm{wt} \% \mathrm{SiO}_{2}-\mathrm{H}_{2} \mathrm{O}$ to investigate the laminar and turbulent flows within a square-type solar thermal system. The thermal performance of FPSC was found to increase at the specified flow rates of $0.5 \mathrm{~kg} \mathrm{~min}^{-1}$ and

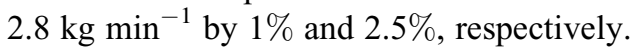

Allotropes of carbon such as single-walled carbon nanotubes (SWCNTs), multi-walled carbon nanotubes (MWCNTs), graphene nanoplatelets (GrNPs), graphene oxide (GO), and graphene ( $\mathrm{Gr}$ ) have recently been tested as absorbing mediums rather than industrial samples inside the FPSCs. ${ }^{27-30}$ Said et al. ${ }^{27,31}$ studied the theoretical and 


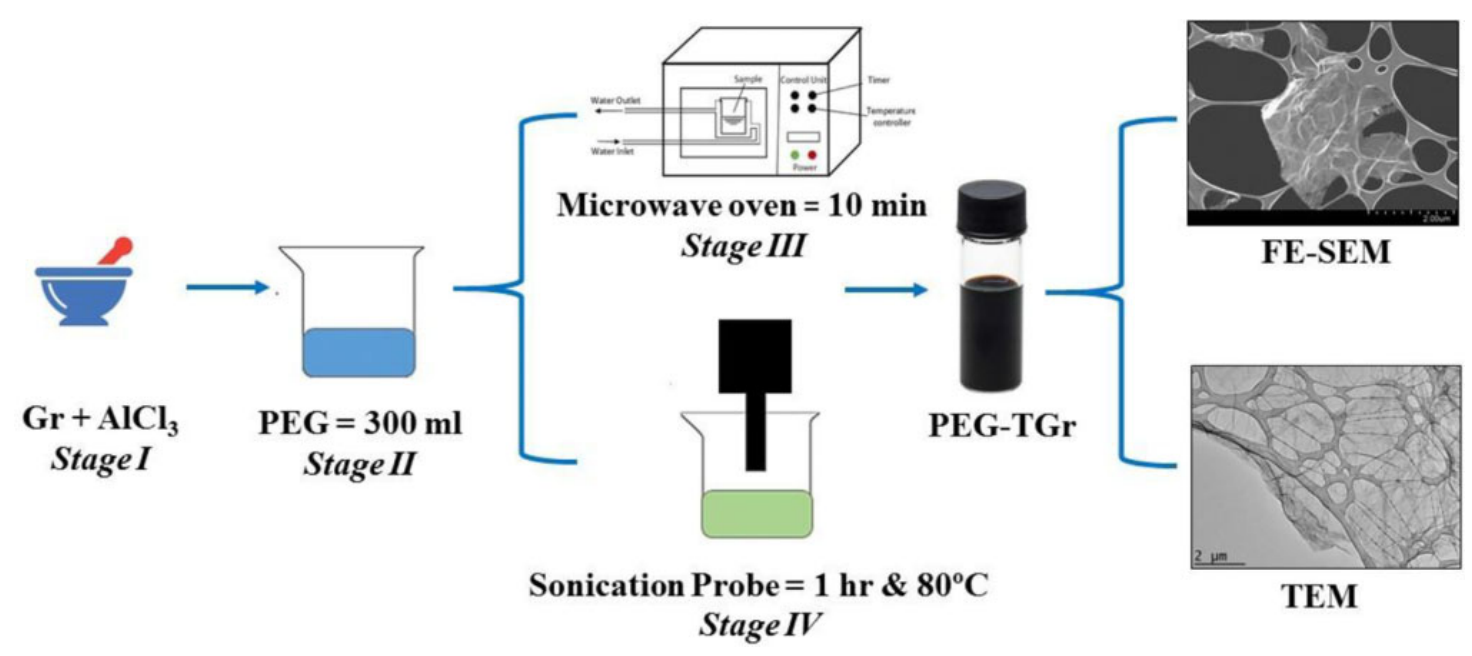

Figure I. Schematic illustration of the acid treatment for PEG-TGr. PEG-TGr: pentaethylene glycol-thermally treated graphene.

experimental effect of using SWCNT- $\mathrm{H}_{2} \mathrm{O}$ nanofluid on heat transport, pressure loss, and exergy performance of the solar collector. Their tests revealed that when loading $3 \mathrm{wt} \%$ SWCNT- $\mathrm{H}_{2} \mathrm{O}$ at a flow rate of $0.5 \mathrm{~kg} \mathrm{~min}^{-1}$, the energy and exergy performance of the system reached approximately $95 \%$ and $26.25 \%$, respectively. Yousefi et al. ${ }^{32}$ experimentally analyzed the effectiveness implications of using MWCNT- $\mathrm{H}_{2} \mathrm{O}$ inside a solar collector. The solar energy efficiency was found to be increased at a mass flow rate of $2 \mathrm{~kg} \mathrm{~min}^{-1}$ by $28.6 \%$ for $0.2 \mathrm{wt} \%$ MWCNT$\mathrm{H}_{2} \mathrm{O}$. The experimental effects of application GrNPs- $\mathrm{H}_{2} \mathrm{O}$ nanofluid on the FPSC performance were studied by Vakili et al. ${ }^{28}$ The study found energy efficiency improvements of up to $13.5 \%, 19.7 \%$, and $23.2 \%$ for $0.0005 \%, 0.001 \%$, and $0.005 \%$ of GrNPs-nanofluid mass fractions, respectively, at a flow rate of $0.9 \mathrm{~kg} \mathrm{~min}^{-1}$. Ahmadi et al. ${ }^{33}$ evaluated the effect of $\mathrm{Gr}-\mathrm{H}_{2} \mathrm{O}$ nanofluids on the efficiency of the FPSC theoretically and experimentally. Their conclusions exhibited that the collector energy performance was enhanced by $18.9 \%$ with $0.02 \mathrm{wt} \% \mathrm{Gr}-\mathrm{H}_{2} \mathrm{O}$ at $0.9 \mathrm{~kg} \mathrm{~min}^{-1}$. In recent research, Akram et al. ${ }^{34}$ explored the implications of Clove-treated graphene nanoplatelet (CGNP)- $\mathrm{H}_{2} \mathrm{O}$ for enhancing the efficacy of the FPSC. Experimental results indicated that the peak energy efficiency was obtained by using $0.1 \mathrm{wt} \%$ CGNP- $\mathrm{H}_{2} \mathrm{O}$ nanofluid in the solar collector with a flow rate of $0.0260 \mathrm{~kg} \mathrm{~s}^{-1} \mathrm{~cm}^{-2}$, which was about $18.2 \%$ higher than $\mathrm{H}_{2} \mathrm{O}$ as working fluid for the same conditions.

Further work is required to understand the carbonbased nanofluids within the solar collector as the absorption mediums. The investigations were performed using different operating conditions such as; the working fluids were DW and aqueous nanofluids with specific mass percentages. The working fluids flowed to the FPSC system under different operating conditions such as different inlet temperatures, heat flow densities, and fluid mass flow rates. A regression model was developed based on the collected data to estimate the thermal efficiency of FPSC.

\section{Materials and methods}

\section{Synthesis of PEG-TGr- $\mathrm{H}_{2} \mathrm{O}$ nanofluids}

The pristine $\mathrm{Gr}$ in few-layer nanoparticles was supplied from the company VCN Co., Ltd, Bushehr, Iran. for nanomaterials. Different chemicals such as pentaethylene glycol (PEG; average Mn of 250, purity 90\%), aluminum chloride, hydrochloric acid, $N, N$-dimethylformamide, and tetrahydrofuran were locally sourced from Sigma-Aldrich (M) Sdn. Bhd, Selangor, Malaysia. The standard protocol for experimentation is schematically shown in Figure 1. The current study followed the same chemical reactions with some changes to synthesize the nanomaterials as in the previous study. ${ }^{35}$ A precision balance (OHAUS PA214) was used to measure the accurate weight of nanoparticles. An ultrasonication probe (Vibra-Cell, Sonics, VC 750) was used for dispersing the nanomaterial in the base fluid and also for preparing the covalently functionalized PEGthermally treated graphene (PEG-TGr).

\section{Experimental system}

The experimental configuration for evaluating the energy efficiency of the indoor FPSC based Gr nanofluids is shown in Figure 2. The test rig setup included a flat-plate collector, control and measurement equipment, cooled $\mathrm{H}_{2} \mathrm{O}$ bath, flow piping loop, and a data logger. For the movement of the working fluid, a motorized centrifugal pump was used in the forced convection system. Table 1 gives detailed specifications for the portion of the collector used in this 


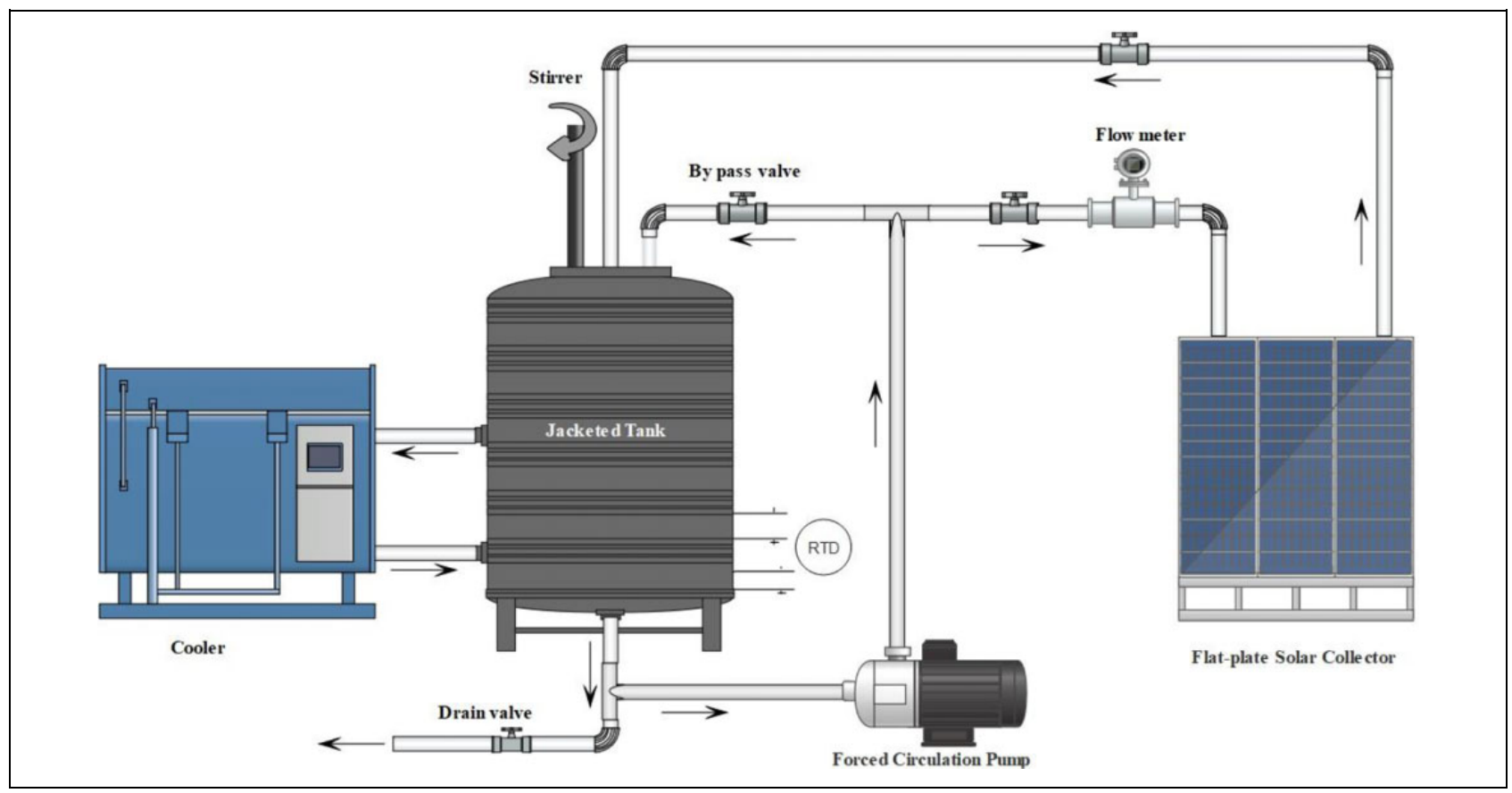

Figure 2. The schematic diagram of the thermal flat-plate collector setup.

Table I. Technical specifications of the FPSC.

\begin{tabular}{|c|c|c|}
\hline Specifications & Dimension & Unit \\
\hline \multicolumn{3}{|l|}{ FPSC } \\
\hline Length & 1.135 & $\mathrm{~m}$ \\
\hline Width & 0.6 & $\mathrm{~m}$ \\
\hline Thickness & 0.005 & $\mathrm{~m}$ \\
\hline Absorptance & 0.95 & - \\
\hline Material & $\mathrm{Cu}$ & - \\
\hline \multicolumn{3}{|l|}{ Area } \\
\hline Collector occupied & 0.681 & $\mathrm{~m}^{2}$ \\
\hline Absorption & 0.464 & $\mathrm{~m}^{2}$ \\
\hline \multicolumn{3}{|l|}{ Header pipe } \\
\hline Outer diameter & 0.022 & $\mathrm{~m}$ \\
\hline Inner diameter & 0.0196 & $\mathrm{~m}$ \\
\hline Length & 0.6 & $\mathrm{~m}$ \\
\hline Material & $\mathrm{Cu}$ & - \\
\hline \multicolumn{3}{|l|}{ Riser pipe } \\
\hline Outer diameter & 0.0127 & $\mathrm{~m}$ \\
\hline Inner diameter & 0.0105 & $\mathrm{~m}$ \\
\hline Length & 1.02 & $\mathrm{~m}$ \\
\hline Spacing & 0.128 & $\mathrm{~m}$ \\
\hline Material & $\mathrm{Cu}$ & - \\
\hline \multicolumn{3}{|l|}{ Glass cover } \\
\hline Thickness & 0.005 & $\mathrm{~m}$ \\
\hline Transmittance & 0.83 & - \\
\hline Emissivity & 0.88 & - \\
\hline \multicolumn{3}{|l|}{ Slope of collector } \\
\hline Tilt angle & 30 & $\circ$ \\
\hline
\end{tabular}

$\mathrm{Cu}$ : copper; FPSC: flat-plate solar collector.

research. The $\mathrm{Cu}$ absorber plate was soldered directly through the $\mathrm{Cu}$ riser tubing contact length (Figure 3). Isowool ceramic fiber (thermal conductivity of $0.07 \mathrm{~W}$

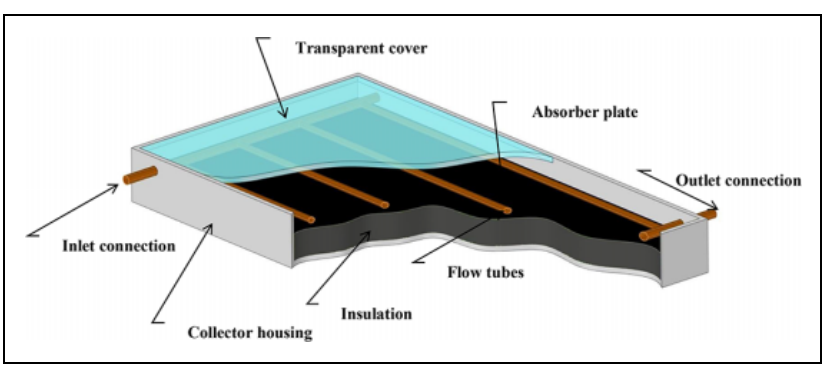

Figure 3. The main components of a FPSC. FPSC: flat-plate solar collector.

$\mathrm{m}^{-1} \dot{\mathrm{c}} \mathrm{K}^{-1}$ at $400^{\circ} \mathrm{C}$ ) was used underneath the absorber plate as a high-temperature insulating sheet. The versatile adhesive heater was connected to an adjustable voltage transformer to supply the heating system with the equivalent constant heat flux. Super-fast-response self-adhesive thermocouples (T-type, model: SA1XL-T-72, Omega, USA, Omega Engineering Inc., Norwalk, Connecticut) were used to test the surface temperature of the riser tubes used in this work and the absorber plate. The 12 calibrated thermocouples were axially mounted in four separate locations along the absorber plate surface and two riser tubes. Besides, two resistance thermometers (resistance temperature detectors (RTDs); type PT100, Omega, USA) were installed at the intake and exhaust pipes to control the absorbing medium's bulk temperatures. To analyze and monitor the experimental data, an 18-channel Ecolog paperless recorder system (EC18, Kuala Lumpur, MALAYSIA.) has facilitated the connection of thermocouples and RTDs with a data logger. 


\section{Data processing and errors analysis}

The useful energy $\left(Q_{\mathrm{u}}\right)$ can be determined from the equation accordingly ${ }^{36}$

$$
Q_{\mathrm{u}}=\dot{m} C_{\mathrm{p}}\left(T_{\mathrm{o}}-T_{\mathrm{i}}\right)
$$

where, $\dot{m}, C_{\mathrm{p}}$, and $T_{\mathrm{o}}-T_{\mathrm{i}}$ refer to the mass flow rate, the fluid specific heat capacity of nanofluids, and the difference between the output/input liquid temperature, respectively.

A further illustration of the useful energy amount is given based on the distinction between the energy absorbed, and heat loss of the system is shown below ${ }^{36}$

$$
Q_{\mathrm{u}}=F_{\mathrm{R}} A_{\mathrm{c}}\left(G_{\mathrm{T}}(\tau \alpha)-U_{\mathrm{L}}\left(T_{\mathrm{i}}-T_{\mathrm{a}}\right)\right)
$$

Therefore, $F_{\mathrm{R}}, A_{\mathrm{c}}, G_{\mathrm{T}}, \tau \alpha$, and $U_{\mathrm{L}}$ refer to heat loss coefficient, the collector aperture area, global solar irradiation, transmittance-absorptance product, and collector heat loss coefficient related to aperture area, respectively. However $T_{\mathrm{i}}-T_{\mathrm{a}}$ denotes the difference between the nanofluid input/room temperatures and $\eta_{\mathrm{c}}$ is solar collector thermal efficiency that is generally referred to the Hottel-WhillierBliss equation, which is expressed as ${ }^{36}$

$$
\begin{gathered}
\eta_{\mathrm{c}}=\frac{Q_{\mathrm{u}}}{A_{\mathrm{c}} G_{\mathrm{T}}}=\frac{\dot{m} C_{\mathrm{p}}\left(T_{\mathrm{o}}-T_{\mathrm{i}}\right)}{A_{\mathrm{c}} G_{\mathrm{T}}} \\
\eta_{\mathrm{c}}=F_{\mathrm{R}}(\tau \alpha)-F_{\mathrm{R}} U_{\mathrm{L}} \frac{T_{\mathrm{i}}-T_{\mathrm{a}}}{G_{\mathrm{T}}}
\end{gathered}
$$

Consequently, the uncertainty in the value of FPSC efficiency calculated from the experimental data can be determined using the following relation ${ }^{33}$

$$
\begin{gathered}
\frac{\partial_{\eta_{\mathrm{c}}}}{\eta_{\mathrm{c}}}=\left[\left(\frac{\partial_{m}}{\dot{m}}\right)^{2}\right. \\
+\left(\frac{\partial_{C_{\mathrm{p}}}}{C_{\mathrm{p}}}\right)^{2}+\left(\frac{\partial_{G_{\mathrm{T}}}}{G_{\mathrm{T}}}\right)^{2}+\left(\frac{\partial_{A_{\mathrm{c}}}}{A_{\mathrm{c}}}\right)^{2} \\
\left.+\left(\frac{\partial_{\left(T_{\mathrm{o}}-T_{\mathrm{i}}\right)}}{\left(T_{\mathrm{o}}-T_{\mathrm{i}}\right)}\right)^{2}\right]^{0.5}
\end{gathered}
$$

Ranges and accuracies of instruments and fluid properties were shown in Table 2. The total uncertainty in the overall efficiency of the process is approximately $3.37 \%$ after the measurement procedure.

\section{Thermophysical and characterization properties}

The thermal conductivities of nanofluids and base fluid samples were calculated using a thermal analyzer (model: KD2 Pro, Decagon, Pullman, WA, USA). An average of 16 readings was obtained over $4 \mathrm{~h}$ for each temperature setting to determine the dispersal stability of the nanofluids. The MCR 302 Rheometer (Anton Paar, Austria) was employed for testing the dynamic viscosity of $\mathrm{H}_{2} \mathrm{O}$ and PEG-TGr- $\mathrm{H}_{2} \mathrm{O}$ nanofluids. Density meter Easy-D40, Mettler Toledo, Ohio, United States. was utilized for the density measurements of liquid samples with an accuracy of $\pm 10^{-4} \mathrm{~g} \mathrm{~cm}^{-3}$. For

\begin{tabular}{|c|c|c|}
\hline $\begin{array}{l}\text { Instrument and sensor } \\
\text { type }\end{array}$ & Range & $\begin{array}{l}\text { Uncertainty } \\
(\%)\end{array}$ \\
\hline Type-T thermocouple & $0-300^{\circ} \mathrm{C}$ & $\pm 0.1^{\circ} \mathrm{C}$ \\
\hline RTD (PTI00) sensor & $0-200^{\circ} \mathrm{C}$ & $\pm 0.1^{\circ} \mathrm{C}$ \\
\hline $\begin{array}{l}\text { Burkert flow meter } \\
\text { (Type SE32, Bürkert, } \\
\text { Ingelfingen, Germany) }\end{array}$ & $0.3-81 \mathrm{~min}^{-1}$ & $\pm 1 \%$ \\
\hline Power supply (AC clamp & $200 / 600 \mathrm{~V}$ & \pm 1 \\
\hline $\begin{array}{l}\text { meter, Kyoritsu, Tokyo, } \\
\text { Japan) }\end{array}$ & $200 / 600 \mathrm{~A}$ & \pm 1.5 \\
\hline $\begin{array}{l}\text { Thermal conductivity KD2 } \\
\text { pro (Decagon) }\end{array}$ & $0.2-2 \mathrm{~W} \mathrm{~m}^{-1} \dot{\mathrm{c}} \mathrm{K}^{-1}$ & \pm 5 \\
\hline $\begin{array}{l}\text { Dynamic viscosity (Physica, } \\
\text { MCR 302, Anton Paar) }\end{array}$ & $-150^{\circ} \mathrm{C}$ to $+1000^{\circ} \mathrm{C}$ & \pm 1 \\
\hline $\begin{array}{l}\text { Density Mettler Toledo } \\
\text { (DE-40, Ohio, United } \\
\text { States) }\end{array}$ & $0-3 \mathrm{~g} \mathrm{~cm}^{-3}$ & \pm 1 \\
\hline $\begin{array}{l}\text { Specific heat (DSC 8000, } \\
\text { PerkinElmer, } \\
\text { Massachusetts, United } \\
\text { States) }\end{array}$ & $0.01-300^{\circ} \mathrm{C} \mathrm{min}^{-1}$ & \pm 2 \\
\hline
\end{tabular}
accuracy and reliability considerations, measures were taken at least three times per sample at each temperature. DSC 8000-PerkinElmer estimated the fluids specific heat
Table 2. List of ranges and accuracies for instruments and fluid properties.

RTD: resistance temperature detector.

with an accuracy of $\pm 1.0 \%$. Scanning electron microscope (SEM, Tescan VEGA3, Czechia) was utilized for the morphology and elemental study of functionalized synthesized powders.

\section{Results and discussion}

\section{Morphological and thermophysical properties}

A visual analysis of GrNPs surface using SEM to the identification of contaminants or unknown particles, the cause of failure and interactions between materials is shown in Figure 4(a) and (b). In addition to surface evaluation, SEM analysis is utilized for particle characterization. The high magnification, high-resolution imaging of our SEM analysis supports the determination of the number, size, and morphology of Gr particles. The surfactantstabilized nanofluids were deposited on a silicon ( $\mathrm{Si}$ ) wafer to obtain the SEM micrographs and distributions. Also, Figure 4 shows that nanoparticles do not have an agglomeration, so they have appeared in an aggregation mechanism and are well distributed. SEM micrographs also reveal that the covalent synthesizing of Gr allows the wrinkled structures actively. Energy-dispersive X-ray spectroscopy (EDX) provides further understanding of the surface of Gr during the SEM analysis process. EDX analysis is used to acquire the elemental composition of a sample and allows for a more quantitative result than that provided by only SEM analysis. The combination of SEM and EDX analysis offers chemical composition and elemental investigation - providing a comprehensive metallurgical evaluation. The spectrum study of GrNPs with 


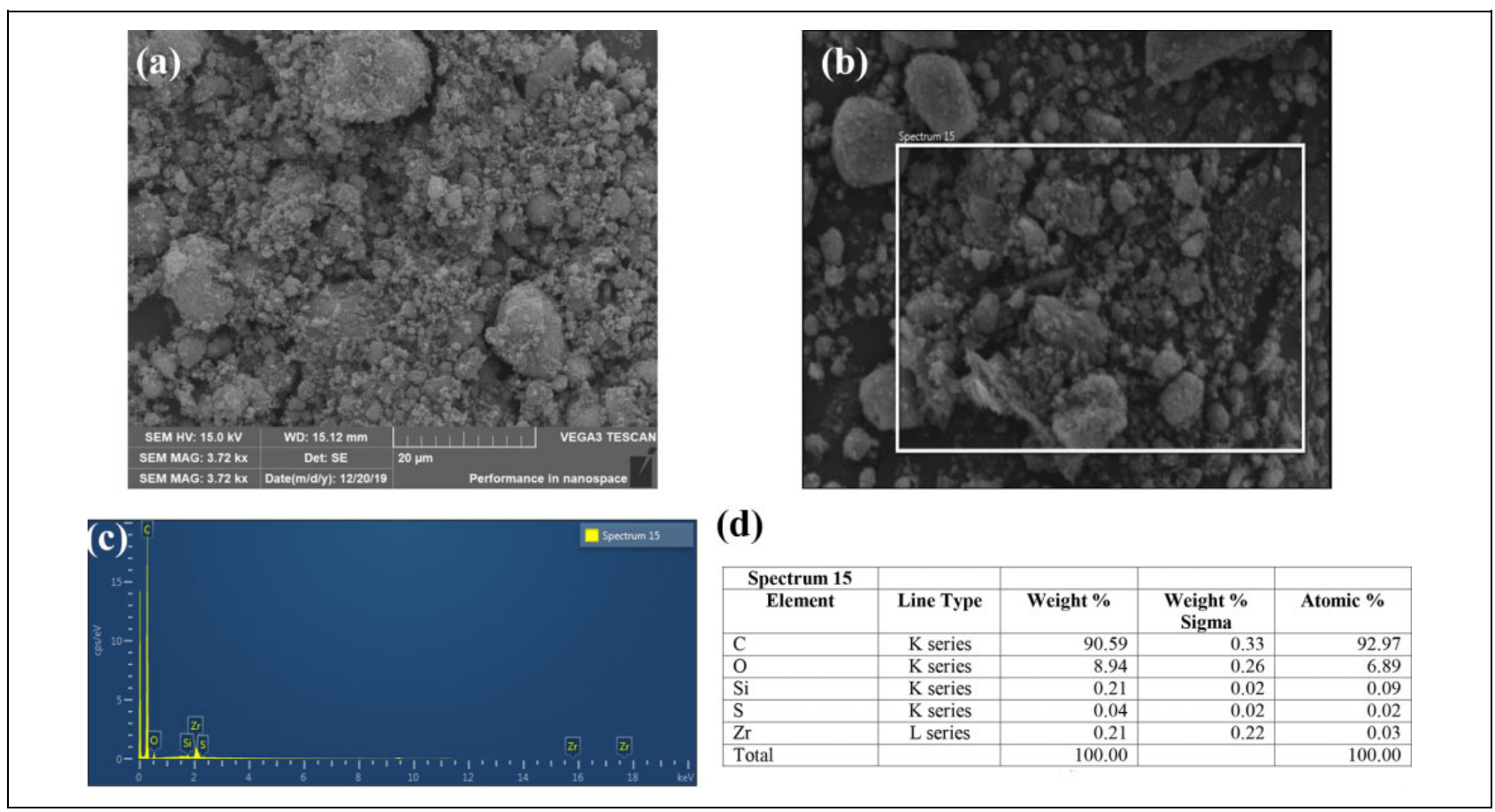

Figure 4. SEM and EDX mapping analysis of the Gr nanoparticles: (a) SEM microimage, (b) electron image of spectrum I5, (c) EDX mapping analysis, and (d) EDX elemental analysis. SEM: scanning electron microscopy; EDX: energy-dispersive X-ray spectroscopy; Gr: graphene.

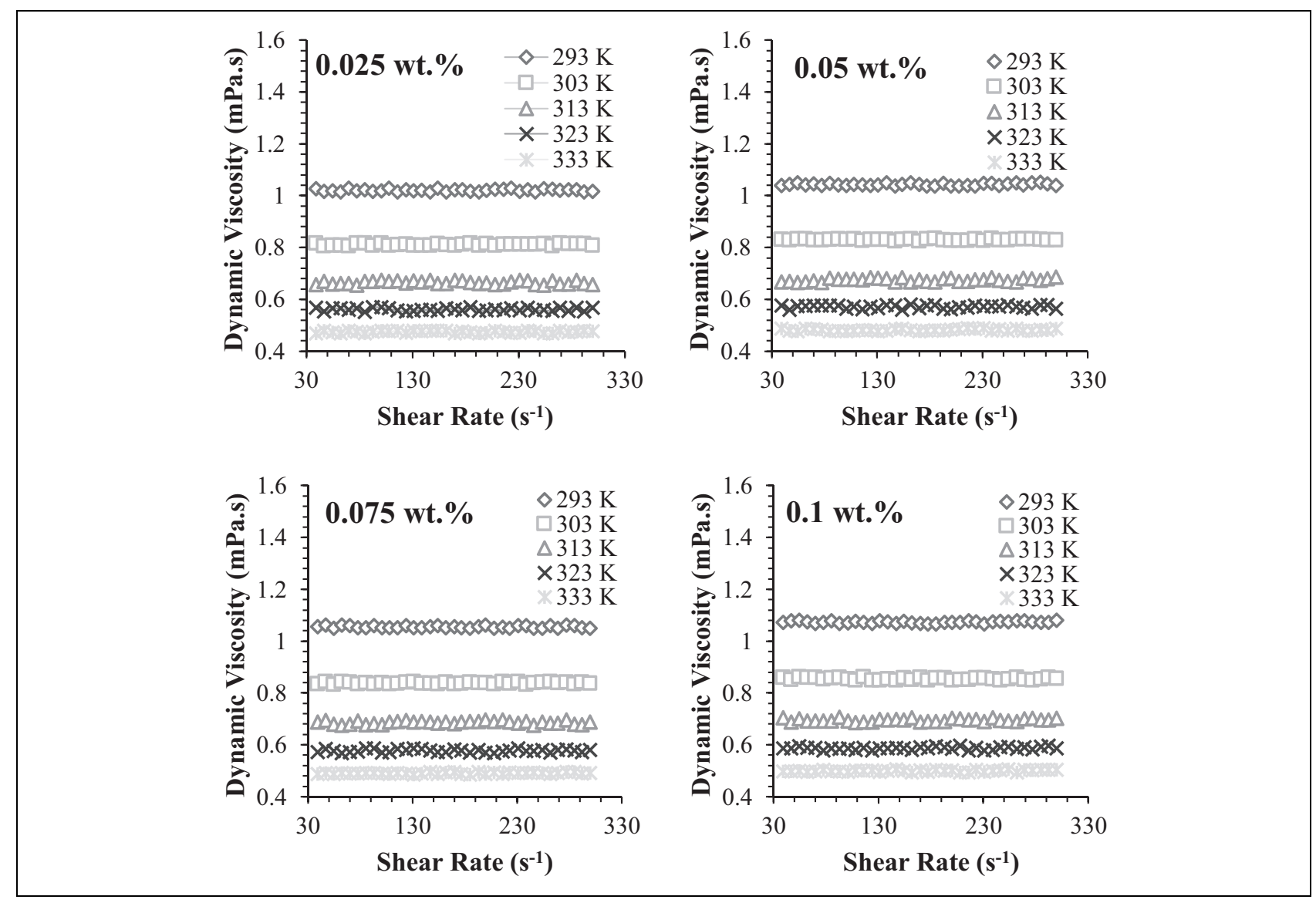

Figure 5. The measured values of dynamic viscosity against shear rate for PEG-TGr nanofluids at different temperatures and mass fractions. ${ }^{37}$ PEG-TGr: pentaethylene glycol-thermally treated graphene. 


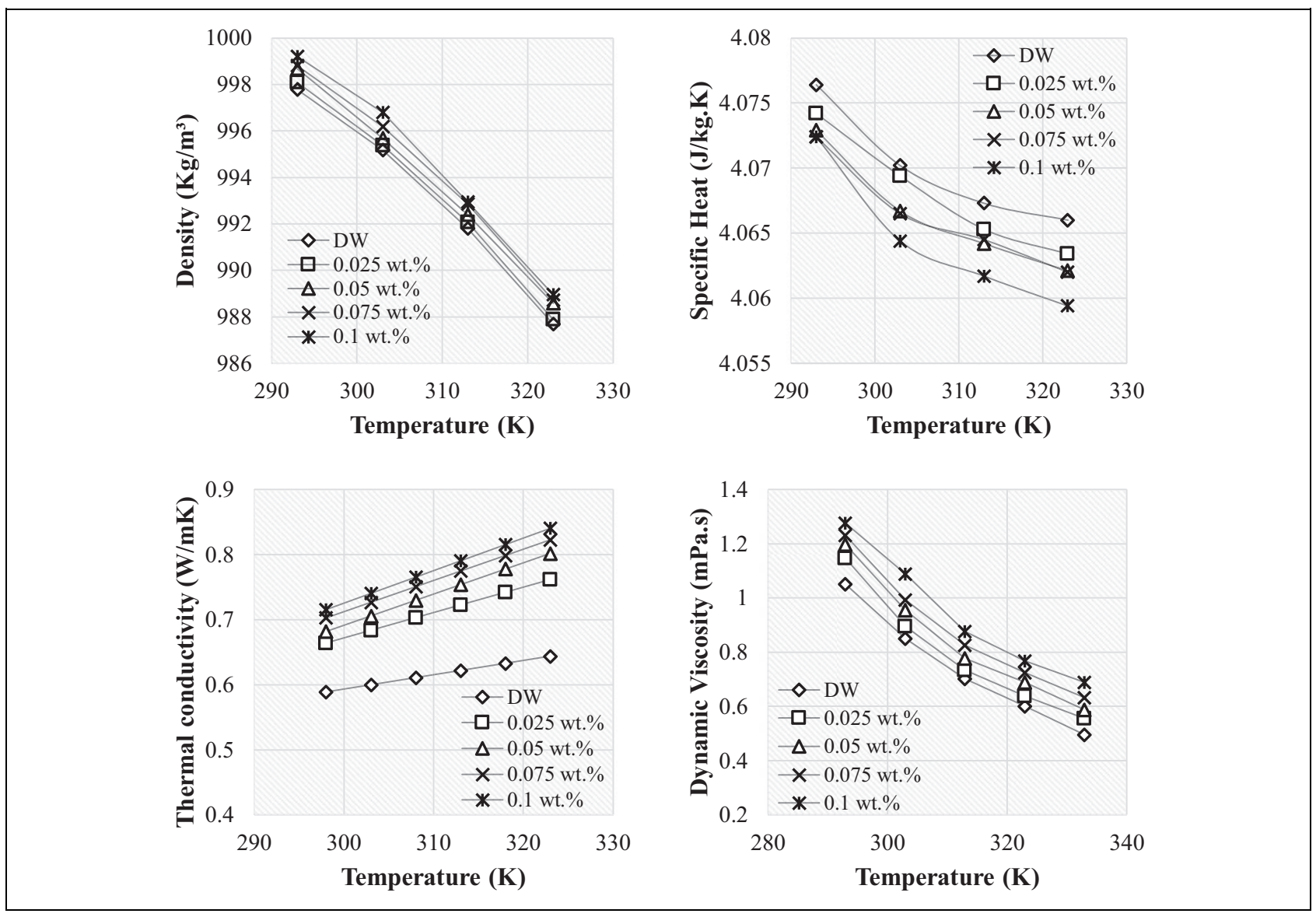

Figure 6. Thermophysical properties for DW and PEG-TGr nanofluids at different temperatures and mass fractions. ${ }^{37} \mathrm{DW}:$ distilled water; PEG-TGr: pentaethylene glycol-thermally treated graphene.

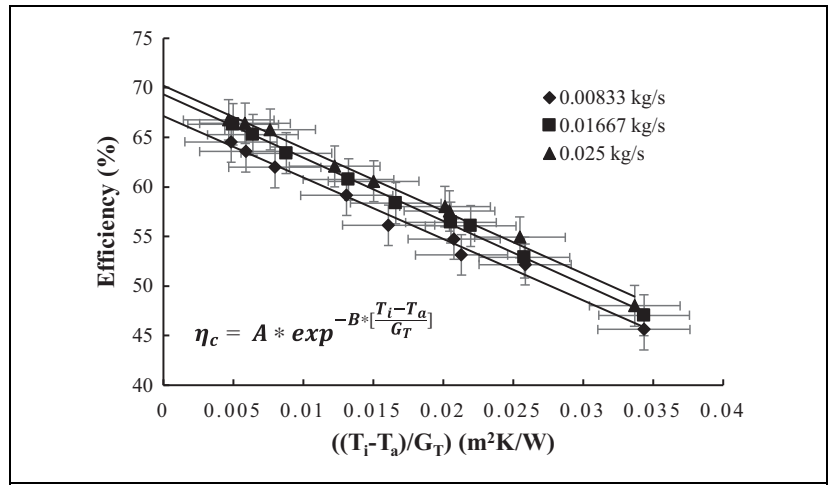

Figure 7. The experimental values of the collector efficiency for DW against the reduced temperature coefficient at different fluid mass flow rates. DW: distilled water.

EDX is shown in Figure 4(c) and (d). The EDX measurements show five elements, such as carbon, oxygen, $\mathrm{Si}$, sulfur (S), and zirconium (Zr). GrNPs show a carbon content of $92.97 \%$ and an atomic oxygen content of $6.89 \%$. While the atomic content of $\mathrm{Si}, \mathrm{S}$, and $\mathrm{Zr}$ is $0.09 \%, 0.02 \%$ and $0.03 \%$, respectively.
The measured values of viscosity are plotted in Figure 5 as a function of shear rate for $\mathrm{H}_{2} \mathrm{O}$-based PEG-TGr nanofluids at different temperatures and weight concentrations. From the figure, it was observed that viscosity increases as weight concentration increases and decreases as temperature increases. Furthermore, it can also be found that the behavior of $\mathrm{H}_{2} \mathrm{O}$-based PEG-TGr nanofluids was quite Newtonian with almost constant viscosity with different values of shear rate. Figure 6 presents the results of thermal conductivity, dynamic viscosity, density, and specific heat capacity for base $\mathrm{H}_{2} \mathrm{O}$ and PEG-TGr-nanofluids. ${ }^{37-39}$ Measurements of thermophysical properties were performed at different temperatures testing of 303,313 , and $323 \mathrm{~K}$. The data collected showed that the density, dynamic viscosity, and thermal conductivity were improved by increasing the nanoparticles mass percentage in the DW, but the specific heat capacity was reduced. The maximum thermal conductivity increase value was $30.48 \%$ compared with $\mathrm{H}_{2} \mathrm{O}$ at $323 \mathrm{~K}$. Whereas an increase in viscosity of $27.53 \%$ was observed at a temperature of $303 \mathrm{~K}$ for the $0.1 \mathrm{wt} \%$ PEGTGr-NPs. Just $0.1 \%$ was the most significant increase in density measurements. The real heat nanofluids, however, dropped by $2.9 \%$ at $0.1 \mathrm{wt} \%$ PEG-TGr-NPs. 
Table 3. Heat gain and heat loss coefficients at different PEGTGr-NPs mass fractions and varying flow rates.

\begin{tabular}{llccl}
\hline Fluid & Mass flow rate $\left(\mathrm{kg} \mathrm{s}^{-1}\right)$ & $F_{\mathrm{R}}(\tau \alpha)$ & $F_{\mathrm{R}} U_{\mathrm{L}}$ & \multicolumn{1}{c}{$R^{2}$} \\
\hline $\mathrm{DW}$ & 0.00833 & 0.671 & 11.273 & 0.989 \\
& 0.01667 & 0.693 & 10.862 & 0.9966 \\
& 0.025 & 0.702 & 10.187 & 0.992 \\
$0.025 \mathrm{wt} \%$ & 0.00833 & 0.714 & 11.533 & 0.9942 \\
& 0.01667 & 0.736 & 10.889 & 0.9942 \\
& 0.025 & 0.756 & 10.333 & 0.9942 \\
0.05 wt\% & 0.00833 & 0.728 & 11.831 & 0.9944 \\
& 0.01667 & 0.751 & 10.985 & 0.9944 \\
& 0.025 & 0.772 & 10.524 & 0.9944 \\
0.075 wt\% & 0.00833 & 0.736 & 12.211 & 0.9982 \\
& 0.01667 & 0.759 & 11.147 & 0.9982 \\
& 0.025 & 0.780 & 10.643 & 0.9982 \\
0.1 wt\% & 0.00833 & 0.742 & 12.532 & 0.9954 \\
& 0.01667 & 0.766 & 11.238 & 0.9954 \\
& 0.025 & 0.787 & 10.839 & 0.9954 \\
& & & &
\end{tabular}

PEG-TGr-NPs: pentaethylene glycol-thermally treated graphene nanoplatelets; DW: distilled water.

\section{Analysis of thermal efficiency using $\mathrm{H}_{2} \mathrm{O}$}

Initially, the working fluid (DW) flowed inside the collector setup to verify the validity, reliability, and readability of the test section results before the nanofluids were conducted in the next phase. It is observed that the data reproduced well, test rig was highly accurate and remains within an error of $<1 \%$. Figure 7 exhibits the collected data of $\mathrm{H}_{2} \mathrm{O}$ run for the FPSC performance under the operating settings of different $\mathrm{H}_{2} \mathrm{O}$ mass flow rates versus the lowered temperature factor $\left(\left(T_{\mathrm{i}}-T_{\mathrm{a}}\right) / G_{\mathrm{T}}\right)$. After flowing more $\mathrm{H}_{2} \mathrm{O}$ to the system $\left(0.01667-0.025 \mathrm{~kg} \mathrm{~s}^{-1}\right)$, the FPSC efficiency showed an increment by about $2.75 \%$ and $3.44 \%$, respectively. The explanation for increasing the FPSC efficiency was due to the improved $\mathrm{H}_{2} \mathrm{O}$ flow rate $\left(\mathrm{H}_{2} \mathrm{O}\right.$ mass flow rate), reduction of flat-plate surface temperature, and minimization of the overall heat loss. The coefficients of the heat gain $\left(F_{\mathrm{R}}(\tau \alpha)\right)$ and heat loss $\left(F_{\mathrm{R}} U_{\mathrm{L}}\right)$ for the working fluid of $\mathrm{H}_{2} \mathrm{O}$ are listed in Table 3. Table 3 demonstrates that the $F_{\mathrm{R}}(\tau \alpha)$ value of the collector was highest when the $\mathrm{H}_{2} \mathrm{O}$ was flowing at $0.025 \mathrm{~kg} \mathrm{~s}^{-1}$, whereas the $F_{\mathrm{R}} U_{\mathrm{L}}$ value was lowest for the same situation. Therefore, based upon equation (4), FPSC performance can be maximized at the highest flow rates.

\section{Analysis of thermal efficiency using nanofluids}

Figure 8(a) to (c) shows the measured values of FPSC efficiency for $\mathrm{H}_{2} \mathrm{O}$ and PEG-TGr-NPs nanofluids against the lowered temperature factor $\left(\left(T_{\mathrm{i}}-T_{\mathrm{a}}\right) / G_{\mathrm{T}}\right)$ under the operating conditions of different PEG-TGr-NPs concentrations and changed fluid mass flow rates. From Figure 8, it can be concluded that by using $\mathrm{H}_{2} \mathrm{O}$-suspended PEG-TGrNPs for any concentration, the thermal performance was enhanced. As the fluid flow rate of circulating nanofluid
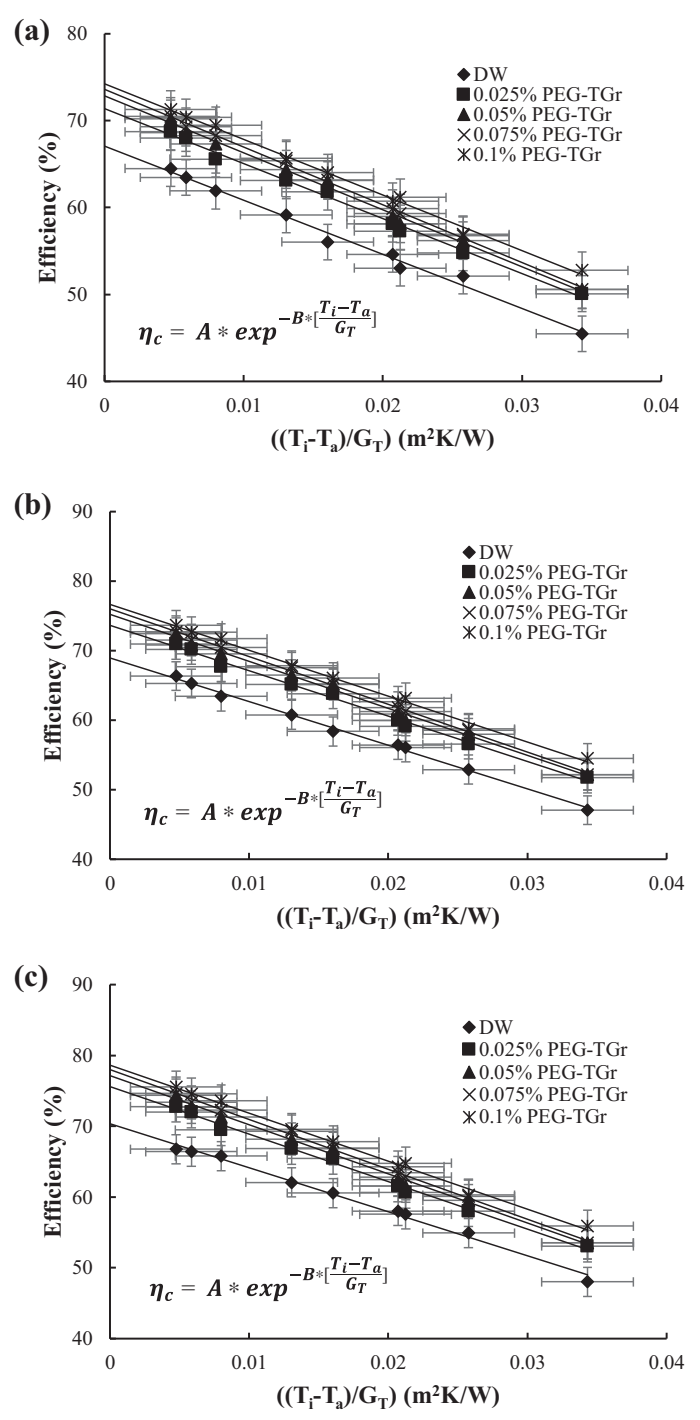

Figure 8. Thermal efficiency for $\mathrm{H}_{2} \mathrm{O}$ and PEG-TGr- $\mathrm{H}_{2} \mathrm{O}$ nanofluids at different mass fractions: (a) $0.00833 \mathrm{~kg} \mathrm{~s}^{-1}$, (b) $0.01667 \mathrm{~kg}$ $\mathrm{s}^{-1}$, and (c) $0.025 \mathrm{~kg} \mathrm{~s}^{-1}$. $\mathrm{H}_{2} \mathrm{O}$ : water; PEG-TGr: pentaethylene glycol-thermally treated graphene.

varies from $0.00833 \mathrm{~kg} \mathrm{~s}^{-1}, 0.01667 \mathrm{~kg} \mathrm{~s}^{-1}$, and $0.025 \mathrm{~kg}$ $\mathrm{s}^{-1}$, the FPSC efficiency was improved up to $10.6 \%, 11 \%$, and $13.1 \%$, respectively. Figure 9(a) to (d) exhibits the influence of PEG-TGr-NPs against the FPSC performance at four different weight concentrations $(0.025,0.05,0.075$ and $0.1 \%$ by mass) under the similar condition of fluid mass flow rate $\left(0.00833,0.01667\right.$ and $\left.0.025 \mathrm{~kg} \mathrm{~s}^{-1}\right)$. As can be seen from Figures 8 and 9, the FPSC thermal performance enhanced when the flowing of PEG-TGrnanofluid was increased from $0.00833 \mathrm{~kg} \mathrm{~s}^{-1}$ to $0.025 \mathrm{~kg}$ $\mathrm{s}^{-1}$ for all the employed samples. The highest increment in the FPSC energy performance corresponding to the reduced temperature parameter was about $13.1 \%$ for the testing conditions of $0.1 \mathrm{wt} \%$ PEG-TGr loading and fluid flow rate of 

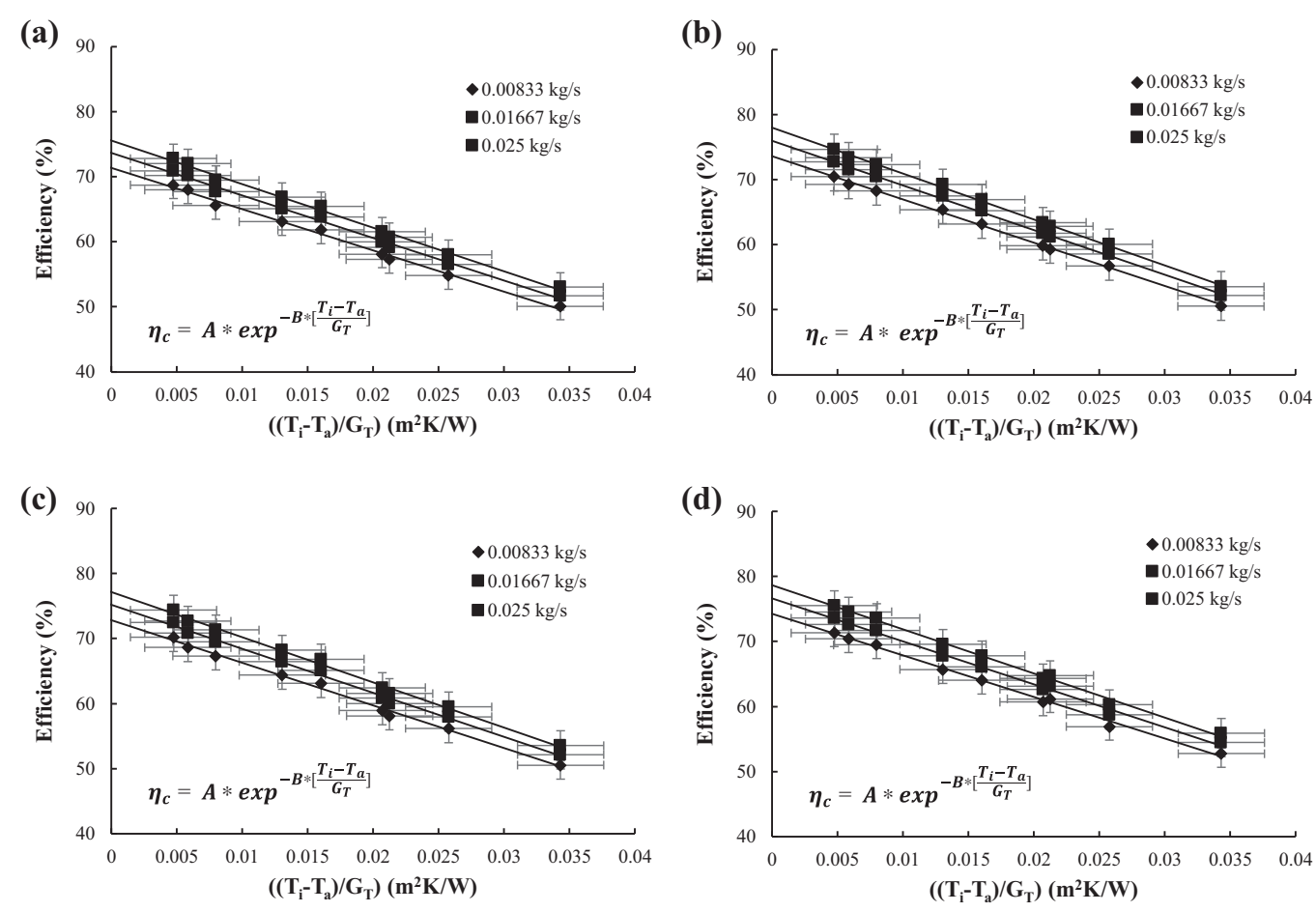

Figure 9. Thermal efficiency for PEG-TGr- $\mathrm{H}_{2} \mathrm{O}$ nanofluids at different fluid mass flow rates: (a) $0.025 \mathrm{wt} \%$, (b) $0.05 \mathrm{wt} \%$, (c) $0.075 \mathrm{wt} \%$, and (d) $0.1 \mathrm{wt} \%$. $\mathrm{H}_{2} \mathrm{O}$ : water; PEG-TGr: pentaethylene glycol-thermally treated graphene.

$0.025 \mathrm{~kg} \mathrm{~s}^{-1}$. The current research findings are consistent with preceding studies by Vakili et al. ${ }^{28}$ and Karami et al. ${ }^{40}$ It was also found that higher PEG-TGr weight fractions contributed to higher input energy absorption, hence resulting in an improvement in the FPSC effectiveness. The heat was distributed evenly across the fluid layers for the low content of Gr nanoparticles; the heat loss at the flow boundary is much lower for the lower concentration of PEG-TGr compared to the higher nanofluid weight fraction in which the uppermost fluid layers are dominated by more heat absorption. This high-temperature region at the wall boundary contributes more spaces for heat losses, thereby decreasing the effectiveness of the collector. Table 4 compares the previous experimental data on using carbon-based nanofluids inside the FPSCs.

The critical factor for improving the FPSC effectiveness by introducing PEG-TGr nanopowder into the base fluid can be described by the following: the specific heat capacity of the nanofluids $\left(C p_{n f}\right)$ to be evaluated is slightly lower than $\left(C p_{b f}\right)$ but the temperature distinction produced by the nanofluids $\left(T_{o}-T_{i}\right)$ is significantly higher than that by the base fluid. A substantial increase in the experimental thermal efficiency has then resulted from the combination of the above two conditions. ${ }^{48-50}$

Table 3 and Figure 10(a) and (b) below illustrate the $F_{\mathrm{R}}(\tau \alpha)$ and $F_{\mathrm{R}} U_{\mathrm{L}}$ for PEG-TGr-DW nanofluids. When the nanofluid flows at a constant flow rate $\left(0.00833 \mathrm{~kg} \mathrm{~s}^{-1}\right)$ and varied Gr weight concentrations (0.025 wt $\%, 0.05$ wt $\%$,
$0.075 \mathrm{wt} \%$, and $0.1 \mathrm{wt} \%), F_{\mathrm{R}}(\tau \alpha)$ values progressively increased by $6.28 \%, 8.49 \%, 9.68 \%$, and $10.53 \%$, respectively, relative to the data of base fluid. The heat absorption factors also showed upward trends for $0.01667 \mathrm{~kg} \mathrm{~s}^{-1}$ flow rate at $0.025 \mathrm{wt} \%, 0.05 \mathrm{wt} \%, 0.075 \mathrm{wt} \%$, and $0.1 \mathrm{wt} \%$ PEGTGr concentrations by up to $6.25 \%, 8.39 \%, 9.54 \%$, and $10.53 \%$, respectively. Meanwhile, given a flow rate of the fluid at $0.025 \mathrm{~kg} \mathrm{~s}^{-1}$, there was an enhancement for $\left(F_{\mathrm{R}}(\tau \alpha)\right)$ by $7.63 \%, 9.90 \%, 11.04 \%$, and $12.01 \%$, respectively, for $0.025 \mathrm{wt} \%, 0.05 \mathrm{wt} \%, 0.075 \mathrm{wt} \%$, and $0.1 \mathrm{wt} \%$ PEG-TGr nanofluids. When flow rate was at the lower range $\left(0.00833 \mathrm{~kg} \mathrm{~s}^{-1}\right)$, the corresponding value of $F_{\mathrm{R}} U_{\mathrm{L}}$ for $0.025 \mathrm{wt} \%, 0.05 \mathrm{wt} \%, 0.075 \mathrm{wt} \%$, and $0.1 \mathrm{wt} \%$ PEGTGr concentrations had increased by $2.31 \%, 4.95 \%, 8.32 \%$, and $11.17 \%$. Meanwhile, at higher fluid mass flow rate $\left(0.025 \mathrm{~kg} \mathrm{~s}^{-1}\right)$, the $F_{\mathrm{R}} U_{\mathrm{L}}$ value incremented by $1.43 \%$, $3.31 \%, 4.48 \%$, and $6.40 \%$ for different concentrations as used in the present work.

\section{Proposed model of thermal efficiency}

New thermal efficiency correlation was developed as a function of the reduced temperature factor $\left(\left(T_{\mathrm{i}}-T_{\mathrm{a}}\right) / G_{T}\right)$ (equation 6). An exponential form was used to derive the FPSC thermal effectiveness based on the experimental data with statistical significance at a confidence level of $95 \%$. A maximum deviation of about $6.782 \%$, standard deviation of about $1.962 \%$, and average deviation of about $4.485 \%$ were 


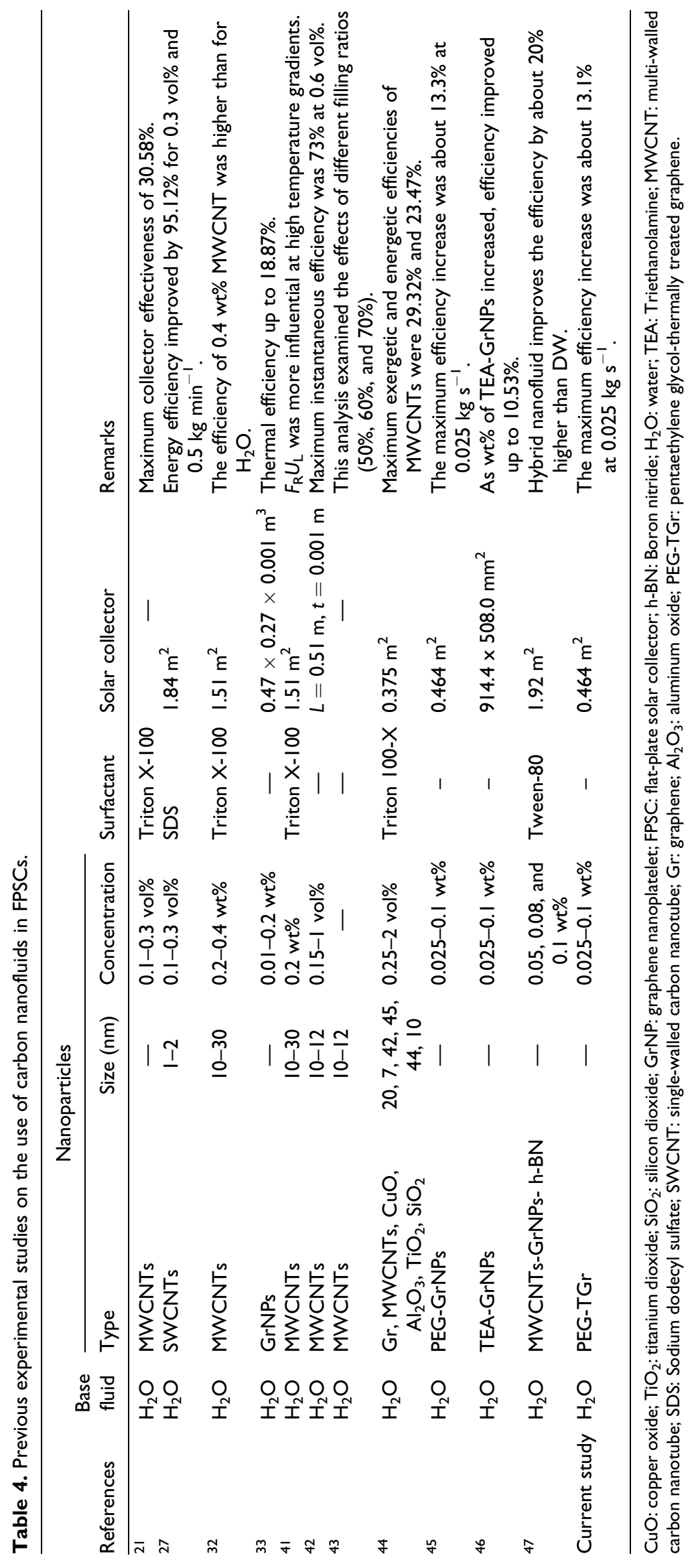




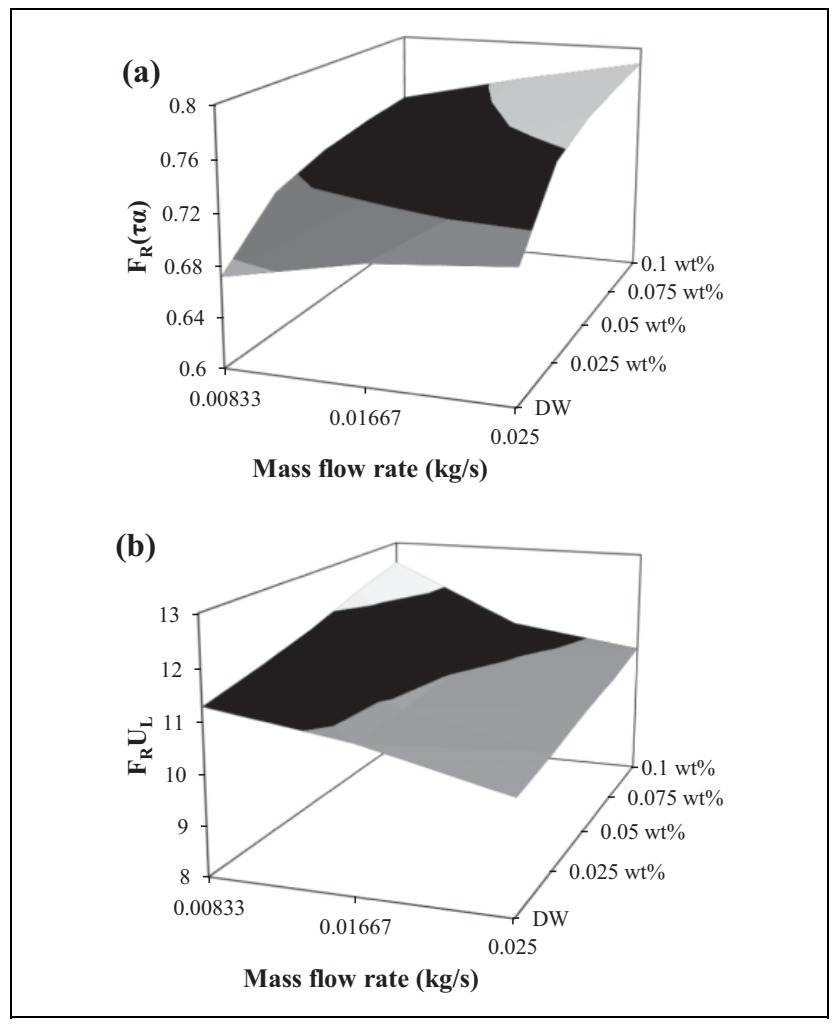

Figure 10. (a) The heat gain coefficient $\left(F_{\mathrm{R}}(\tau \alpha)\right)$ and (b) the heat loss coefficient $\left(F_{R} U_{L}\right)$ for $\mathrm{H}_{2} \mathrm{O}$ and PEG-TGr- $\mathrm{H}_{2} \mathrm{O}$ nanofluids as a function of mass fraction and mass flow rate. $\mathrm{H}_{2} \mathrm{O}$ : water; PEGTGr: pentaethylene glycol-thermally treated graphene.

Table 5. The coefficients of the developed correlations for the FPSC efficiency based $\mathrm{H}_{2} \mathrm{O}$ and nanofluids at different mass flow rates.

\begin{tabular}{lcccc}
\hline Mass flow rate $\left(\mathrm{kg} \mathrm{s}^{-1}\right)$ & Sample $(\mathrm{wt} \%)$ & $A$ & $B$ & $R^{2}$ \\
\hline 0.00833 & DW & 68.073 & 11.2 & 0.9868 \\
& 0.025 & 72.245 & 10.64 & 0.9953 \\
& 0.05 & 73.795 & 10.84 & 0.9936 \\
& 0.075 & 74.655 & 10.93 & 0.9932 \\
& 0.1 & 75.13 & 10.29 & 0.9952 \\
0.01667 & DW & 70.415 & 11.25 & 0.9913 \\
& 0.025 & 74.563 & 10.64 & 0.9953 \\
& 0.05 & 76.162 & 10.84 & 0.9936 \\
& 0.075 & 77.05 & 10.93 & 0.9932 \\
0.025 & 0.1 & 77.54 & 10.29 & 0.9952 \\
& $D W$ & 71.195 & 10.91 & 0.9823 \\
& 0.025 & 76.521 & 10.64 & 0.9953 \\
& 0.05 & 78.162 & 10.84 & 0.9936 \\
& 0.075 & 79.073 & 10.93 & 0.9932 \\
& 0.1 & 79.576 & 10.29 & 0.9952 \\
\hline
\end{tabular}

FPSC: flat-plate solar collector; DW: distilled water; $\mathrm{H}_{2} \mathrm{O}$ : water.

observed between the experimental and proposed correlation values for all the nanofluids examined. The coefficients of the new correlation are presented in Table 5 along with $R^{2}$ values.

$$
\eta_{\mathrm{c}}=A \times \exp ^{-B \times\left[\frac{T_{\mathrm{i}}-T_{\mathrm{a}}}{G_{\mathrm{T}}}\right]}
$$

\section{Conclusions}

The current research aimed to experimentally discuss the impact of using few-layer $\mathrm{Gr}$ in aqueous suspensions as the absorbing medium on the FPSC energy efficiency. Different variables were considered during the investigations, such as various weight concentrations, different fluid flowing rates, different input fluid temperatures, and different input heat rates. After the discussion of the results aforementioned, the following conclusions were drawn;

1. The EDX measurements portray two components present in CF-GrNPs; carbon and oxygen. $\mathrm{Si}, \mathrm{S}$, and $\mathrm{Zr}$ were present as a result of the oxidizing agent and from the substrate. The best enhancements in the thermophysical properties of PEG-TGr-DW relative to the base fluid were recorded as $30.48 \%$ for thermal conductivity at $323 \mathrm{~K}$ and $27.53 \%$ for dynamic viscosity at $0.1 \mathrm{wt} \%$ PEG-TGr and $303 \mathrm{~K}$. The measured density with the maximum concentration value had an increment of $0.1 \%$, whereas the specific heat reduced to $2.9 \%$ for the same concentration of $0.1 \mathrm{wt} \%$ PEG-TGr- $\mathrm{H}_{2} \mathrm{O}$.

2. Improvements in the FPSC energy efficiency relied on increases in heat flux intensity and nanofluid mass flowing rate of PEG-TGr. A reduction in thermal energy was reported as the nanofluid input temperature was raised. For the measured mass flowing rates of $0.00833,0.01667$, and $0.025 \mathrm{~kg} \mathrm{~s}^{-1}$, the highest collector performance increases are $10.6 \%, 11 \%$, and $13.1 \%$, respectively, with $0.1 \mathrm{wt} \%$ nanofluid.

3. The highest observed increment in the heat loss coefficient $\left(F_{\mathrm{R}} U_{\mathrm{L}}\right)$ and the heat gain coefficient $\left(F_{\mathrm{R}}(\tau \alpha)\right)$ was $11.17 \%$ and $12.01 \%$, respectively, for $0.1 \mathrm{wt} \%$ PEG-TGr concentration at 0.00833 and $0.025 \mathrm{~kg} \mathrm{~s}^{-1}$ mass flow rates.

4. New thermal efficiency correlation was developed as a function of the reduced temperature factor $\left(\left(T_{\mathrm{i}}-T_{\mathrm{a}}\right) / G_{\mathrm{T}}\right)$.

\section{Acknowledgment}

The authors gratefully acknowledge the financial support from Universiti Teknologi Malaysia, operated by the Research Management Center (RMC).

\section{Declaration of conflicting interests}

The author(s) declared no potential conflicts of interest with respect to the research, authorship, and/or publication of this article. 


\section{Funding}

The author(s) disclosed receipt of the following financial support for the research, authorship, and/or publication of this article: This work was supported by the Universiti Teknologi Malaysia, operated by the Research Management Center (RMC), under the Research University grant number 04E76.

\section{ORCID iD}

Omer A Alawi (D) https://orcid.org/0000-0002-8598-4461

\section{References}

1. Khodabandeh E, Safaei MR, Akbari S, et al. Application of nanofluid to improve the thermal performance of horizontal spiral coil utilized in solar ponds: geometric study. Renew Energy 2018; 122: 1-16.

2. Mallah AR, Mohd Zubir MN, Alawi OA, et al. Plasmonic nanofluids for high photothermal conversion efficiency in direct absorption solar collectors: fundamentals and applications. Sol Energy Mater Sol Cells 2019; 201: 110084.

3. Sarafraz MM, Tlili I, Tian Z, et al. Smart optimization of a thermosyphon heat pipe for an evacuated tube solar collector using response surface methodology (RSM). Phys A Stat Mech Appl 2019; 534: 122146.

4. Raj P and Subudhi S. A review of studies using nanofluids in flat-plate and direct absorption solar collectors. Renew Sust Energy Rev 2018; 84: 54-74.

5. Goshayeshi HR and Safaei MR. Effect of absorber plate surface shape and glass cover inclination angle on the performance of a passive solar still. Int J Numer Methods Heat Fluid Flow 2019; 30(6): 3183-3198.

6. Olia H, Torabi M, Bahiraei M, et al. Application of nanofluids in thermal performance enhancement of parabolic trough solar collector: state-of-the-art. Appl Sci 2019; 9: 463.

7. Sarafraz MM and Safaei MR. Diurnal thermal evaluation of an evacuated tube solar collector (ETSC) charged with graphene nanoplatelets-methanol nano-suspension. Renew Energy 2019; 142: 364-372.

8. Sarafraz MM, Tlili I, Baseer MA, et al. Potential of solar collectors for clean thermal energy production in smart cities using nanofluids: experimental assessment and efficiency improvement. Appl Sci 2019; 9(9): 1877.

9. Sarafraz MM, Tlili I, Tian Z, et al. Thermal evaluation of graphene nanoplatelets nanofluid in a fast-responding HP with the potential use in solar systems in smart cities. Appl Sci 2019; 9(10): 2101.

10. Peng Y, Zahedidastjerdi A, Abdollahi A, et al. Investigation of energy performance in a U-shaped evacuated solar tube collector using oxide added nanoparticles through the emitter, absorber and transmittal environments via discrete ordinates radiation method. J Therm Anal Calorim 2020; 139(4): 2623-2631.

11. Zhou X, Wang Y, Zheng K, et al. Comparison of heat transfer performance of $\mathrm{ZnO}-\mathrm{PG}, \alpha-\mathrm{Al}_{2} \mathrm{O}_{3}-\mathrm{PG}$, and $\gamma-\mathrm{Al}_{2} \mathrm{O}_{3}-\mathrm{PG}$ nanofluids in car radiator. Nanomater Nanotechnol 2019; 9: 1847980419876465.
12. Choi SUS and Eastman JA. Enhancing thermal conductivity of fluids with nanoparticles. ASME Int Mech Eng Congr Expo 1995; 66: 99-105.

13. Sakhaei SA and Valipour MS. Performance enhancement analysis of the flat plate collectors: a comprehensive review. Renew Sust Energy Rev 2019; 102: 186-204.

14. Yarmand H, Gharehkhani S, Shirazi SFS, et al. Study of synthesis, stability and thermo-physical properties of graphene nanoplatelet/platinum hybrid nanofluid. Int Commun Heat Mass Transf 2016; 77: 15-21.

15. Liu WI, Malekahmadi O, Bagherzadeh SA, et al. A novel comprehensive experimental study concerned graphene oxide nanoparticles dispersed in water: synthesise, characterisation, thermal conductivity measurement and present a new approach of RLSF neural network. Int Commun Heat Mass Transf 2019; 109: 104333.

16. Safaei MR, Ahmadi G, Goodarzi MS, et al. Heat transfer and pressure drop in fully developed turbulent flows of graphene nanoplatelets-silver/water nanofluids. Fluids 2016; 1(20): $1-2$.

17. Bahiraei M, Mazaheri N, Aliee F, et al. Thermo-hydraulic performance of a biological nanofluid containing graphene nanoplatelets within a tube enhanced with rotating twisted tape. Powder Technol 2019; 355: 278-288.

18. Zayed ME, Zhao J, Du Y, et al. Factors affecting the thermal performance of the flat plate solar collector using nanofluids: a review. Sol Energy 2019; 182: 382-396.

19. He Q, Zeng S, and Wang S. Experimental investigation on the efficiency of flat-plate solar collectors with nanofluids. Appl Therm Eng 2014; 88: 165-171.

20. Tomy AM, Ahammed N, Subathra MSP, et al. Analysing the performance of a flat plate solar collector with silver/water nanofluid using artificial neural network. Procedia Comput Sci 2016; 93: 33-40.

21. Rajput NS, Shukla DDB, and Sharma SK. Thermal analysis of MWCNT/distilled water nanofluid on the efficiency of flat plate solar collector. Int J Mech Eng Technol 2017; 8: 233-240.

22. Sundar LS, Singh MK, Punnaiah V, et al. Experimental investigation of $\mathrm{Al}_{2} \mathrm{O}_{3}$ /water nanofluids on the effectiveness of solar flat-plate collectors with and without twisted tape inserts. Renew Energy 2018; 119: 820-833.

23. Kiliç F, Menlik T, and Sözen A. Effect of titanium dioxide/ water nanofluid use on thermal performance of the flat plate solar collector. Sol Energy 2018; 164: 101-108.

24. Sharafeldin MA, Gróf G, and Mahian O. Experimental study on the performance of a flat-plate collector using $\mathrm{WO}_{3}$ /water nanofluids. Energy 2017; 141: 2436-2444.

25. Sharafeldin MA and Gróf G. Experimental investigation of flat plate solar collector using $\mathrm{CeO}_{2}$-water nanofluid. Energy Convers Manag 2018; 155: 32-41.

26. Noghrehabadi A, Hajidavaloo E, and Moravej M. Experimental investigation of efficiency of square flat-plate solar collector using $\mathrm{SiO}_{2} /$ water nanofluid. Case Stud Therm Eng 2016; 8: 378-386. 
27. Said Z, Saidur R, Sabiha MA, et al. Thermophysical properties of single wall carbon nanotubes and its effect on exergy efficiency of a flat plate solar collector. Sol Energy 2015; 115: 757-769.

28. Vakili M, Hosseinalipour SM, Delfani S, et al. Experimental investigation of graphene nanoplatelets nanofluid-based volumetric solar collector for domestic hot water systems. Sol Energy 2016; 131: 119-130.

29. Vincely DA and Natarajan E. Experimental investigation of the solar FPC performance using graphene oxide nanofluid under forced circulation. Energy Convers Manag 2016; 117 : $1-11$.

30. Safaei MR, Goshayeshi HR, and Chaer I. Solar still efficiency enhancement by using graphene oxide/paraffin nano-PCM. Energies 2019; 12(10): 2002.

31. Said Z, Saidur R, Rahim NA, et al. Analyses of exergy efficiency and pumping power for a conventional flat plate solar collector using SWCNTs based nanofluid. Energy Build 2014; 78: 1-9.

32. Yousefi T, Veisy F, Shojaeizadeh E, et al. An experimental investigation on the effect of MWCNT- $\mathrm{H}_{2} \mathrm{O}$ nanofluid on the efficiency of flat-plate solar collectors. Exp Therm Fluid Sci 2012; 39: 207-212.

33. Ahmadi A, Ganji DD, and Jafarkazemi F. Analysis of utilizing graphene nanoplatelets to enhance thermal performance of flat plate solar collectors. Energy Convers Manag 2016; 126: 1-11.

34. Akram N, Sadri R, Kazi SN, et al. An experimental investigation on the performance of a flat-plate solar collector using eco-friendly treated graphene nanoplatelets-water nanofluids. J Therm Anal Calorim 2019; 138(1): 609-621.

35. Alawi OA, Sidik NAC, Kazi SN, et al. Graphene nanoplatelets and few-layer graphene studies in thermo-physical properties and particle characterization. $J$ Therm Anal Calorim 2019; 135(2): 1081-1093.

36. Hawwash AA, Abdel Rahman AK, Nada SA, et al. Numerical investigation and experimental verification of performance enhancement of flat plate solar collector using nanofluids. Appl Therm Eng 2018; 130: 363-374.

37. Alawi OA, Mallah AR, Kazi SN, et al. Thermophysical properties and stability of carbon nanostructures and metallic oxides nanofluids: experimental approach. J Therm Anal Calorim 2019; 135(2): 1545-1562.

38. Goodarzi M, Kherbeet AS, Afrand M, et al. Investigation of heat transfer performance and friction factor of a counterflow double-pipe heat exchanger using nitrogen-doped, graphene-based nanofluids. Int Commun Heat Mass Transf 2016; 76: 16-23.
39. Maithani R, Kumar A, Gholamali Zadeh P, et al. Empirical correlations development for heat transfer and friction factor of a solar rectangular air passage with spherical-shaped turbulence promoters. J Therm Anal Calorim 2020; 139(2): 1195-1212.

40. Karami M, Akhavan-Behabadi MA, Dehkordi MR, et al. Thermo-optical properties of copper oxide nanofluids for direct absorption of solar radiation. Sol Energy Mater Sol Cells 2016; 144: 136-142.

41. Yousefi T, Shojaeizadeh E, Veysi F, et al. An experimental investigation on the effect of $\mathrm{pH}$ variation of MWCNT- $\mathrm{H}_{2} \mathrm{O}$ nanofluid on the efficiency of a flat-plate solar collector. Sol Energy 2012; 86: 771-779.

42. Chougule SS, Sahu SK, and Pise AT. Thermal performance of two phase thermosyphon flat-plate solar collectors using nanofluid. J Sol Energy Eng 2014; 136: 14503.

43. Chougule SS and Sahu SK. Performance of carbon nanotubes-water nanofluid charged wickless heat pipe flat plate solar collectors having different filling ratio. J Sol Energy Eng 2015; 137: 24501.

44. Verma SK, Tiwari AK, and Chauhan DS. Experimental evaluation of flat plate solar collector using nanofluids. Energy Convers Manag 2017; 134: 103-115.

45. Alawi OA, Mohamed Kamar H, Mallah AR, et al. Thermal efficiency of a flat-plate solar collector filled with pentaethylene glycol-treated graphene nanoplatelets: an experimental analysis. Sol Energy 2019; 191: 360-370.

46. Sarsam WS, Kazi SN, and Badarudin A. Thermal performance of a flat-plate solar collector using aqueous colloidal dispersions of graphene nanoplatelets with different specific surface areas. Appl Therm Eng 2020; 172: 115142.

47. Hussein OA, Habib K, Muhsan AS, et al. Thermal performance enhancement of a flat plate solar collector using hybrid nanofluid. Sol Energy 2020; 204: 208-222.

48. Sarafraz MM, Safaei MR, Tian Z, et al. Thermal assessment of nano-particulate graphene-water/ethylene glycol (WEG 60:40) nano-suspension in a compact heat exchanger. Energies 2019; 12: 1929.

49. Goodarzi M, Tlili I, Tian Z, et al. Efficiency assessment of using graphene nanoplatelets-silver/water nanofluids in microchannel heat sinks with different cross-sections for electronics cooling. Int J Numer Methods Heat Fluid Flow 2019: 30(1): 347-372.

50. Bahiraei M, Kiani Salmi H, and Safaei MR. Effect of employing a new biological nanofluid containing functionalized graphene nanoplatelets on thermal and hydraulic characteristics of a spiral heat exchanger. Energy Convers Manag 2019; 180: $72-82$. 